\title{
Die fenomenologie van T.T. Cloete
}

\author{
Hein Viljoen \\ Departement Algemene Taal- en \\ Literatuurwetenskap \\ Potchefstroomse Universiteit vir CHO \\ POTCHEFSTROOM
}

\begin{abstract}
The phenomenology of T.T. Cloete

This article is an exploration of the way phenomena are treated in the poetry of T.T. Cloete. Four important aspects of Cloete's way of looking are discussed, viz. the collecting eye that connects everything with everything, the eye that discovers correspondences, the deological eye that reads signs of God's presence, and the reflecting eye. A critique of reflection is developed by means of a more detailed analysis of "Blydskap" (Joy). These four ways of seeing indicate links between Cloete's poetry and Husserl's Phenomenology.
\end{abstract}

\section{Inleiding}

Wie Cloete, soos hy ons self geleer het, op die woord af lees, kom gou af op 'n aantal werkwoorde van sterk en durende aksie soos "bedrywig", "doenig" en "ywerig" wat myns insiens iets belangriks van Cloete se poësie verraai. In "Herbenutting" $(A n: 3)^{1}$ staan daar byvoorbeeld: "Die dooie pikkewyn dryf in die see/ bedrywig". Selfs die dooie dier is nog aktief besig met hierdie so kenmerkende aksie by Cloete: om aktief deel te word van 'n groter geheel; om die geheel saam te stel. Dit is 'n religieuse soort bedrywigheid hierdie - die Een, veral, wat werk, is God - emstig of speels, verborge of op kosmiese skaal. Hy sit of "[werskaf bedrywig] met nukleone". Of Hy is "ywerig veraf lag-lag in wentelende gasmassas aan die werk" ( $A n: 44)$. Dit is myns insiens belangrik dat hierdie woorde dui op aktief besig wees, maar sonder dat hulle 'n spesifieke handeling benoem; hulle dui op besig-wees in sy essensie.

I Die verskillende bundels word soos volg aangedui: Angelliera met $A n$, Jukstaposisie met $J$, Allotroop met $A l$, Idiolek met $I$, Driepas met $D$ en Met die aarde praat met $M a$. 
In hierdie artikel wil ek egter op iets anders af lees: probeer bepaal wat die Cloete-manier van kyk is. Dit gaan vir my oor hoe die spreker (of kyker) hom opstel teenoor hierdie 'volle lewe', teenoor die verskynsels, en wat dit dan te doen het met weet en begryp en selfs wetenskap, oor hoe die kykers in Cloete se poësie die dinge self waarneem. Dit gaan dus, in Cloete se eie woorde in 'n onlangse artikel, oor "die digter se omgaan met die werklikheid" (1994). Een aspek van hierdie verskynsel is fokalisasie, maar dan fokalisasie veral as manier van kyk en nie soseer as 'n verhouding tussen wat die karakter weet en wat die verteller vertel nie $^{2}$.

\section{Aanduidings in die sekondêre literatuur}

Geheel en samehang is baie tipiese Cloete-woorde, nes oog en oor. Die samehangsmotief vorm saam met die motiewe van bedryf en bedrywigheid, insamel en vergaar en die toestandsverandering van dinge vir Schutte (1984:99100) deel van die "volle lewe" waama Cloete se poësie streef. Hierdie volle lewe strek, soos Cloete se lesers sal weet, van triceratops tot by virus, van mot tot by God, van nukleone en disseldons tot by gasmassas en swart gate; kortom van die mikrokosmos tot by die makrokosmos, met al die mooi, verhewe en lelike banale dinge daartussen ingesluit - veral die mens en sy doenighede.

Die manier van kyk in Cloete se poësie is al dikwels deur resensente opgemerk. Brink (1985) wys byvoorbeeld op die intieme samehang van waameem en benoem in "landskap" en "meelyfvoel" uit Allotroop, waaruit blyk dat die kyk self skeef is, maar dat "al die skeefkyke saam dan tog deelname aan 'n Groot Geheel (...) impliseer". Grové (1987:149) bemerk verskillende waarnemers in die 3de afdeling, "(hife is in the eye of the beholder)", van Idiolek. Hy meen daar kan onderskei word tussen 'n oog wat waarneem en wat skep, 'n oog wat "bloot vergaar", een wat uitsoek, een wat "nagmerries oproep". Sy slotsom is dat "die beginsel van jukstaposisie" sterk eenheidskeppend in hierdie bundel is: "moontlikheid teenoor werklikheid, skepping naas na-skepping, duplikasie, transkripsie, perifrase, teks teenoor teks - 'n manier van kyk wat die basis vorm van Cloete se metaforiek en bepalend is vir die aard van sy vers". Hoewel dit paradoksaal klink, stem ek saam met Grové se aanspraak dat jukstaposisie by Cloete nie net 'n digterlike tegniek is nie, maar 'n manier van kyk: bykans al

2 Hiermee bedoel ek die onderskeid tussen fokalisasie as manier van kyk (as "relatie tussen de visie en datgene wat 'gezien', waargenomen word", soos Mieke Bal, 1980:108) dit sien, en Genette (1980:189) se siening dat dit neerkom op 'n verskil tussen wat die karakter weet en wat die verteller vertel. 
Cloete se gedigte ontplooi binne 'n sterk spanning tussen twee pole - meestal mens en God, maar baie dikwels ook tussen makrokosmos en mikrokosmos.

Gräbe (1985) noem die titel Allotroop "'n karakterisering-in-die-kleine van Cloete se (poëtiese) kyk op die werklikheid; die teenstellende pole van mooi of aangenaam en lelik of onaangenaam in alle moontlike verskyningsvorme het ná en náás mekaar bestaansreg, is interafhanklik en kan albei in en deur die poësie verestetiseer word". Sy meen ook dat Allotroop die saak 'n stap verder voer as Angelliera en Jukstaposisie deurdat dit uiteenlopende dinge herleibaar maak "tot dieselfde grondvorm".

Venter (1988; 1991) gee myns insiens 'n belangrike aanloop tot 'n beter begrip van Cloete se manier van kyk. Venter (1988) maak oortuigend 'n saak daarvoor uit dat die dualisme tussen 'n meganiese liggaam en 'n bewuste gees in die filosofie van Descartes 'n moontlike interteks is vir die vierde afdeling van Jukstaposisie. Sy beklemtoon die rol van die bewussyn in die 'wysheid' wat Cloete teenoor die wysheid van Descartes stel en wys op woordooreenkomste tussen die verskillende gedigte, wat veral met weet en wysheid te doen het. Sy wys op ooreenkomste met uitsprake van Descartes, soos cogito ergo sum. Haar interessante en breed uitgewerkte siening gaan egter myns insiens nie ver genoeg in die erkenning van die groot belang van die cogito in Cloete se poësie nie. Sy lees ook nie die sleutelwoord transendentaal myns insiens raak genoeg nie.

Waarom transendentaal onder andere so belangrik is, sal myns insiens duidelik word uit ' $n$ analise van vier fasette van Cloete se digterlike kyk. Die vier fasette is die versamelsien, die sien van korrespondensies, die deologiese oog en die fenomenologie van refleksie.

\section{Versamelsien: "Stuk-stuk verbeel aan die geheel"}

Soos duidelik is uit die resensies wat ek aangehaal het, sien Cloete dinge van uiteenlopende aard saam. Opposisies soos hoog/laag, heilig/profaan, mooi/lelik word saamgedink. Uit al die onderdele word die groot geheel saamgestel. Daar is 'n drif om die samehang te vind. Die dinge verskyn selde op hulle eie; hulle word altyd deel van die groot sisteem, soos in "Strandwandeling" ( $J: 44)$ :

\footnotetext{
... egels en geel seesterre tuimel

vermenigvuldig uit die getypoel

tot in die verste hemel
}

Reeds Angelliera is deur Pretorius (1981:83) geprys vir “... die vindingryke ontginning van die sluitmotief van die harmoniese samehang van dinge, en die Goddelike perspektief waardeur hierdie sentrale idee sy uiting vind". Ander 
kere oorskou die kyker die hele kosmos, stap as't ware met sewemyllaarse daardeur, soos in "big bang" ( $M a: 33$ ) waarin daar 'n geweldige kontras is tussen die onmeetlik uitdyende kosmos en die menslike praatjies "boud en stout".

Hoe kompleks hierdie "versamelsien" ( $D: 181)$ van Cloete is, blyk uit "Herbenutting" ( $A n: 3)$ :

Die dooie pikkewyn dryf in die see

bedrywig. Sy deel haar stink uitnodigend mee.

lewers ooit word alles weer saamgestel

uit haar tot eenmalige sel en sel

en sel word elke deel

deeltyds heel in alle gedaantes van die ewige geheel.

Die titel is 'n tegniese, industriële woord, die vehicle van 'n metafoor wat aandui dat die pikkewyn nugter, wetenskaplik beskou word as deel van 'n universele biologies-ekologiese proses. Perseptueel ${ }^{3}$ is die tyd seker ' $n$ hede, maar eintlik onbepaald, panchronies (vgl. "ooit"). Daar is egter ook 'n uitsig op die ewige, die alomvattende. Ruimtelik begin die gedig by die pikkewyn in die see, maar die perspektief word gou universeel, omvattend, onbeperk: 'n "iewers". Die fokalisasie is dus nie geanker aan 'n spesifieke tyd of plek nie. Daar is ook geen vaste oriëntasiepunt vir die fokalisasie nie. Die fokalisasie is universeel, nie-gefokaliseer. Dit sou dus beskryf kon word as kosmies, wetenskaplik, universeel, maar ook dinamies: daar is ' $n$ universele krag in die pikkewyn wat haar deel laat word van die geheel.

Psigologies-kognitief word hier 'n redelik wye kennis van biologiese prosesse veronderstel. Daar is min detail, behalwe die sel en die stink. Die saamstellende kyk by Cloete stel duidelik belang in die prosesse - die boindividuele lewensprosesse. Emotief is die fokalisasie redelik onbetrokke, maar daar sit tog energie in - die energie van die lewensprosesse.

Ideologies word die korrespondensies tussen deel en geheel, die idee dat alles met alles saamhang, hier sterk uitgedruk. Die rym van deel op geheel en die herhaling van die $[\mathrm{E}]$ is ikonies daarvan. Hierdie klankherhalings is ook sterk ikonies van die paradoksale saambestaan van deel en geheel. Let op die frases "deel uitnodigend mee" en "elke deel deeltyds heel". "Deel" word veelseggend

3 Die leser sal hierin Rimon-Kenan (1983) se verskillende fasette van fokalisasie herken. Meer kategorieë is myns insiens egter nodig om Cloete se fokalisasie mee te beskryf. 
op "ewige geheel" gerym, nes "sel" rym op die woord vir die geheel, "saamgestel", waarvan die klanke weer herhaal word in "eenmalige" en "gedaantes". Hierdie rymwoorde het die klanke van die geheelwoorde, maar 'n deelbetekenis.

"Uit haar tot eenmalige sel" kan sintakties saamgelees word met saamstel, maar ook met heel word. Hierdie dubbele sintaksis (apokoinou) druk die deel word van die geheel ook ikonies uit: die "eenmalige sel", die deel, is sowel die resultaat van die saamstel, as ook weer die begin van 'n nuwe geheel. Die paradoks van afgebreek word tot sel, deel word van geheel, word gemerk deur die apokoinou.

Die versamelsien is dus 'n geleerde, universele soort sien (soos blyk uit die biologiese kennis wat hier veronderstel word), wyd en alomvattend, onbeperk, maar ook 'n 'taalsien': seker fasette kan net uitgedruk word met digterlike middele soos rym en herhaling. Die versameloog sien ook 'n sterk dinamiek raak in die paradoksale dryf van die pikkewyn.

\section{Die raaksien van korrespondensies: die stelsel van gelykenisse (similitudes)}

Die versamelsien is ook die sien van ooreenkomste, correspondances soos Baudelaire dit genoem het, oral in die skepping. Vorms van die verskillende dele van die skepping herhaal mekaar, soos in die beroemde "Landwandeling" $(\mathrm{J}: 42)$ of in "Oog" (Ma: 9), waar die oog sy vorm terugsien in die aarde en die reënboog, maar weer beeld word van hoe God in die skepping "sy eie norm is".

Ooreenkomste in vorm is onder andere ook die beginsel onderliggend aan die gedig met die titel "Correspondances" ( $A n: 41)$ :

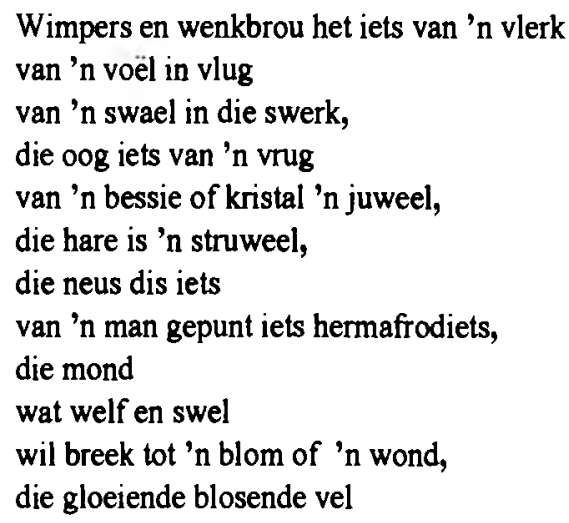


het vrugtedons. Daar, wolke bo 'n afgrond, maal onsekerhede rond.

Hier sien die digterlike oog 'n hele reeks gelykenisse raak wat op verskillende beginsels benus. Daar is ' $n$ hele rits ooreenkomste in vorm: tussen wenkbroue en vlerke, vlieënde voëls of swaeltjies, tussen die oog en ander ronde dinge soos vrugte of bessies, tussen die hare en die struweel ('n formele Nederlandse woord vir "struikgewas"), tussen die neus en die penis. Hierdie gesigsdele maak ander skeppingsdinge na, weerspieël en herhaal hulle op grond van die tweede beginsel in die stelsel van gelykenisse wat Foucault (1973:17-25) onderskei, naamlik emulasie (aemulatio).

In hoofstuk 2 van The Order of Things beskryf Foucault die episteen wat oorheers het tot aan die einde van die sestiende eeu - die episteem waarin gelykenis (resemblance) kennis in die Weste bepaal het. Tot op daardie tydstip, "it was resemblance that largely guided exegesis and the interpretation of texts; it was resemblance that organized the play of symbols, made possible knowledge of things visible and invisible, and controlled the art of representing them" (Foucault, 1973:17). Die heelal het as't ware op homself teruggevou soos die verskillende dele en elemente mekaar weerkaats. Hierin was die vier beginsels van emulasie, nabyheid, analogie en simpatie essensieel, volgens Foucault.

In Cloete se gedig berus die verband tussen "blosende vel" en "vrugtedons" op die eerste beginsel wat Foucault noem: die blosende vel lyk wel soos 'n ryp vrug (aemulatio), maar het dan vrugtedons, omdat dit aan die vrug sit. Hier is die beginsel convenientia, nabyheid: die twee is ruimtelik naby aan mekaar, soos die voël en die swael, die vrug en die bessie, die kristal en die juweel. Dit spreek vanself, binne hierdie stelsel, om mens en dier met mekaar te verbind, want hulle lê naby aan mekaar in die ketting wat afstrek vanaf God, deur die engele tot by dier, plant en mineraal. Deur hierdie convenientia word trekke van die gesig dus met dier, plant en mineraal (in dalende volgorde) vergelyk. Daar is natuurlik ook 'n visuele ooreenkoms en 'n analogie (die derde beginsel) tussen gesigshaartjies en vrugtedons: soos mense gesigshare het, het vrugte dons, afgesien daarvan dat ' $\mathrm{n}$ vrug die vorm en die kleur van die gesig kan hê. Al hierdie ooreenkomste word ondersteun deur die rym, veral veelseggend in "mond"/ "wond" en "iets"/ "hermafrodiets".

Emulasie, anders as nabyheid, kan oor 'n afstand heen werk; dit is 'n gelykenis wat nie kontak nodig het nie. Volgens hierdie beginsel weerspieël dinge mekaar, maar dit is 'n oop stelsel, en die dinge ding met mekaar mee, volgens Foucault (1973:21), soos twee stoeiende figure, om mekaar na te maak, want 
die een is sterker as die ander, die passiewe spieēl van die ander. So ding die blom en die wond mee om afskynsels van die mond te wees en die bessie, kristal en juweel om die oog na te maak. Die stelsel van emulasie vorm dus nie 'n ketting nie, maar 'n reeks konsentriese sirkels wat mekaar weerspieël en met mekaar meeding.

Maar wat van "hermafrodiets"? 'n Hermafrodiet is tweeslagtig en het met ander woorde trekke van albei geslagte. Hier is die neus dus 'n ooreenkoms met die ander geslag, die man, wat beteken dat dit 'n vrou se gesig is wat hier beskryf word - as ons dit nie reeds besef het uit die vergelyking van die oë met juwele, die groot klem op die mond en die bloesende vel nie.

Die slotverse is moeiliker: waar is daardie "wolke bo 'n afgrond"? Die "daar", vermoed ek, slaan op die totaliteit wat hier beskryf word, naamlik die gesig van die vrou, die geliefde. Die onsekerhede speel dus óf op die gesig af, óf in die bewussyn, en "wolke bo 'n afgrond" is die hemelse of geografiese analogie daarvan. Hoe ook al, hierdie onseker dinge verteenwoordig 'n breuk met die sekerhede van die korrespondensies wat in die res van die gedig geproklameer word.

Die reeks "Landskappe" ( $D: 52)$ is vol sulke korrespondensies, veral oor en weer tussen die landskap en die vroulike liggaam, maar ook tussen 'n granietkop en 'n ui, byvoorbeeld ("Granietkop Bosveld"). Om dit te kan raaksien, verg dat die konkrete detail vanaf 'n groot afstand gefokaliseer word en dat die detail tot bykans geometriese vorms gereduseer word.

Ook in "griekse beelde louvre" ( $D: 39-40)$ is daar 'n hele reeks sterk korrespondensies waaruit die reduksie tot vorms duidelik blyk:

$$
\begin{aligned}
& \text { die teer deurskynende marmerplooie pas } \\
& \text { om 'n vrouebors se rondaweltjie } \\
& \text { asof deur die wind afgetas } \\
& \text { en vou in die naweltjie } \\
& \text { soos voor ekstase 'n manshand } \\
& \text { oor 'n teer vrouebors se volte } \\
& \text { voel met die afwagtende binnekant } \\
& \text { se lipteer holte }
\end{aligned}
$$

Nie alleen eggo die bors en die rondawel mekaar nie; manshand en vrouebors herhaal mekaar, nes die vroulike geslagsopening die manshand se binnekant herhaal en albei tewens ook die sagtheid van die lip. Die vorms verdubbel mekaar en pas inmekaar in, ding mee met mekaar en vervul mekaar, en die rym versterk hierdie idee. Die kwaliteite - vol, teer, afwagtend - is belangriker as 
liggaamlike detail, en dit gaan bowendien oor universele herhalings en passings soos deur die korrespondensie-oog waargeneem. Die beginsel van gelykenis is hier, naas die emulering van vorms, die vierde beginsel wat Foucault onderskei, naamlik simpatie. Die liggaamsdele voel met mekaar, deel mekaar se gevoelens. Simpatie, soos Foucault (1973:23-25) dit beskryf, is 'n energie wat onmiddellik werk oor alle tye en afstande heen, dinge aan die beweeg sit en dreig om alles identies te maak aan mekaar. Simpatie moet dus gebalanseer word deur die teenoorgestelde krag van antipatie, wat die apartheid van dinge verseker. Die balans tussen simpatie en antipatie trek die dinge na mekaar toe sodat hulle met mekaar ooreenkom, maar verseker terselfdertyd dat hulle identiteit behoue bly. Dit vorm dus die basis van die drie ander beginsels van gelykenis, omdat alle vorme van ooreenkoms daarkragtens ontstaan.

In "blinde liefde van die blinde meisie" (I: 43) word "holte" en "volte" ook met mekaar gerym, pas die geslagsorgane tot abstrakte vorme gereduseer, ook in mekaar, maar die slotstrofe spel ook 'n dialektiek van wete en leegte uit. Dit is 'n blinde, paradoksale wete van vind met 'n leegte - myns insiens nie soseer liggaamlik nie as eerder ' $n$ wete, 'n verlange wat verseker is dat dit noodwendig vervul sal word, omdat dit so hoort kragtens die korrespondensies en die aantrekkingskrag van simpatie. Wat vir my doel egter belangrik is, is dat die korrespondensies op 'n baie abstrakte vlak lê: op die vlak van bykans geometriese vorms, onbesoedel deur die probleme van werklike menseverhoudinge.

In "Paddaman" $(D: 171$ e.v.) word die lewe in die see volgens dieselfde beginsel beskryf as boordevol herhalings van dinge op land of in ander dele van die skepping; die seelewe word verbluffend en raak in terme van ander skeppingsfere gemetaforiseer, soos in "die stervis onthou om die ster na te boots" of "die pylende inkvis swem snel duikboot".

'n Gedig soos hierdie, hoe ryk aan metafore of hoe deurleef ook al, illustreer egter die epistemologiese armoede van die stelsel van korrespondensies: alles herhaal mekaar, alles is verwant aan mekaar, maar op die lang duur word alles eenders, 'n weerkaatsing van steeds dieselfde dinge in mekaar, 'n verdubbeling daarvan. Geen nuwe kennis kan bykom nie. Dit is 'n ryk van die self-same wat ontstaan: elke ding sien hom in elke ander ding weerspieël, sodat daar niks nuuts onder die son is nie. Hierdie soort kennis is gedoem "to never knowing anything but the same thing, and to knowing that thing only at the unattainable end of an endless journey" (Foucault, 1970:30) - die reis naamlik langs die talle korrespondensies af, nes in "Paddaman". 
Uit die voorbeelde wat ek aangehaal het, blyk dat Cloete se kyk universeel, alomvattend, nie-gefokaliseer bo tyd en ruimte uitgaan. Die digterlike persona oorskou tyd en geskiedenis amper goddelik, maar op 'n wyse wat die samehang van uiters uiteenlopende dinge raaksien, maar dan - en dit is die punt - in hulle essensies, los van tyd en ruimte, spesifieke omstandighede of spesifieke detail.

Ek dink 'n mens sou kon sê die dinge word gesien in 'n fenomenologiese dimensie - 'n universeel, vaste en betroubaar kenbare dimensie, gereduseer of ingeraam uit die 'volle lewe', met dié kwalifikasie daarby dat dié begryplike dimensie ook 'n bo-kognitiewe, liggaamlike of biologiese dimensie kan wees naas die kognitiewe dimensie van die korrespondensies wat beklemtoon word. Dit is ook 'n kyk van 'n groot afstand af, soos die talle meervoude en die baie "die's" in Cloete se poësie getuig.

Hierdie afstandelike kyk sou dus op 'n sekere armoede in Cloete se werk kon dui - ondanks die rykdom daarvan - 'n armoede in die korrespondensiegedigte, want ek meen dat daar ander, nie-korresponderende gedigte van Cloete is (met name die gedigte aan Anna) wat hierdie armoede oorkom. Maar om dit te beredeneer, sal my hier te ver voer.

\section{Die deologiese oog}

Die probleem met die stelsel van korrespondensies, soos Foucault dit stel, is: hoe weet ' $n$ mens van hulle? Watter merktekens is daar byvoorbeeld vir die analogie tussen brein en okkemeut wat ons vind in "landwandeling" $(J: 43)$ ? Die antwoord is: hulle lyk na mekaar. Hierdie ooreenkoms is dan die teken dat okkerneute goed is vir die brein en dat hulle groen skille in die 16de eeu aanbeveel is vir die behandeling van kopvelwonde. Daar is dus ' $n$ stelsel van merktekens (signatures) nodig waarmee die korrespondensies ontdek kan word, meen Foucault (1973:28-29), en hierdie stelsel is juis ooreenkoms, gelykenis. Die stelsel herhaal hom dus in 'n tweede kring van merktekens, met dié verskil dat die tweede kring net effens verplaas is sodat die teken van simpatie 'n analogie is, dié van analogie setel in emulasie, dié van emulasie in byderhandheid, wat weer simpatie as sy teken nodig het. Dit illustreer hoe sterk die stelsel met ander woorde deur ooreenkoms, gelykenis beheers word.

In Cloete se poësie dui die tekens op die ooreenkomste en die hele stelsel is teken van God se aanwesigheid. Ons kan dit, in Cloete se eie woorde heel aan die begin van Angelliera, kenskets as die "teofanie van 'n deoloog" ("Suidpool en senit", $A n:$ 2). Dat 'n fossielblaar in 'n sandwoestyn aanleiding gee tot 'n besonderse ervaring van God - 'n teofanie, in die trant van die epifanie waarna Joyce en Woolf onder andere gestreef het, die oomblik van insig waarin alles deel is van die wonderbaarlike goddelike geheel - is tipies van baie van Cloete 
se gedigte. Daarom dat die digterspersona homself deoloog noem: nie teoloog, student van die Bybel en die godsdienswetenskappe nie, maar student van Deus, van God, en veral dan van God soos Hy "bedrywig werskaf" in die natuur of Hom daarin verberg.

Hier lyk dit of daar 'n duidelik verband kan wees tussen Totius se soek na oogbewyse en Cloete se werkswyse. Soos Totius oogbewyse soek in die skepping om hom (Cloete, 1975:104), soek Cloete na spore, tekens, "insinjes" van God.

Dat God Hom bly verberg, is veral duidelik in die later bundels. Die groot vraag "Hoe sal ek u betrap"?, oftewel, waar vind ek tekens van U?, word gevra in "Ek durf vra" (Ma: 31 ). Hier lys die spreker 'n aantal natuurverskynsels wat hy as tekens van God beskou, maar verklaar ook dat God Hom op 'n veelvuldige wyse openbaar - "so ingewikkeld en naaldekokerooggeruit" dat eintlik elke waarneembare natuurding (sy voorbeelde is wind, lig en lug) as 'n teken van God beskou kan word. Dit geld eintlik alles wat die digter kan raaksien met die drie soorte oë wat Cloete (1994:7) meen die digter nodig het: die mikroskoop, die teleskoop en die oog met duisend lense van die naaldekoker.

"Insinjes" (Ma: 32) wys in heelwat meer besonderhede hoe die proses werk. Die vorms van stuifmeel en van sneeuvlokkies "wys iets van Hom" in hierdie gedig. Hulle is kortom insinjes: onderskeidingstekens van 'n vereniging of die waardigheidstekens van 'n rang of amp, afgelei via Frans uit Latyn insignis, in die oog vallend (HAT). "Vir die nuuskieriges na God - gun ons dit - is dit [sneeuvlokkies in verskillende vorms] hiërogliewe" (vers 5 en 6) - 'n baie belangrike gedagte, want hulle is met ander woorde geheimsinnige beeldskriftekens uit die ou dae. Die sneeuvlokkie gee in sy verskillende gedaantes en eienskappe aanduidings van God wat Hom egter ewe vinnig onttrek en "verdoesel met perspektiewe wat in perspektiewe wegraak" (vers 12) as wat die sneeuvlokkie smelt. In plaas daarvan dat God duideliker sigbaar word, word $\mathrm{Hy}$ in die loop van die gedig eintlik steeds geheimsinniger en onbereikbaarder.

Die insinjes wat hier raakgelees word, is veral visuele ooreenkomste met die sneeuvlokkie se heksagoonvorm. Dit word herhaal en uitgebrei, maar uiteindelik ook opgelos in ooreenkomste met die kleure van 'n pou se stertvere en 'n mot se vlerk. Wat oorbly, is "iets van 'n vermoede" van Hom in die delikate mineraalagtige kleure van blomme en voëls in die vroegaand. Die tekens verskuif en ontglip die beperkings van die waarnemer se oog, die aftas langs al die korrespondensies langs, sodat God al meer verdoesel raak. 
Wat Cloete dus raaklees is nie soos vir Totius, ewigheidsgedagtes of God se gedagtes in die skepping nie. Dit lyk vir my eerder, as ek my op Allotroop moet beroep, of wat raakgelees word, die vormende krag of energie van God is - sy vermoë om van vorm tot vorm te evolueer en in teken na teken Hom te verberg. Pyn is egter, soos duidelik is uit Allotroop, een van die onmiskenbaarste insinjes van God. Hierdie bundel is daarom eintlik 'n fenomenologie van pyn: verskillende vorme van pyn wat vir die digter onmiskenbaar bewus maak van God. In hierdie opsig is die bundel dus ook 'n fenomenologie van God - van God se verskyningsvorme, nes die hele natuur in Cloete se poësie tekens, verskynsels, verskyningsvorme, gelykenisse van God is.

'n Gedig wat myns insiens baie tipies is van een soort omgaan van Cloete met die werklikheid is "alle dinghe bounding line" (I: 83) - sy teenhanger van Totius se "Die wêreld is ons woning nie", wat geëggo word in "smiddags laat" (vers 12) en ander elemente soos die takke, die dakke en die voëls.

Die titel van hierdie gedig is waarskynlik afgelei van Hadewijch se vers "Alle dinghe sijn mi te enghe". Wat my in die gedig opval, is die baie detail, maar veral die vaagheid van daardie detail en die baie meervoude. 'n Kontras word geskep tussen die onbeperktheid en onbepaaldheid van God en die sprekerfokalisator se beperking binne tyd en ruimte en taal, binne "grense en isoglosse". Daarop volg dan twee strofes waarin die spreker sy kennis van sy ruimte verklaar: die straat, die huise, die dakke, die voëls daarbinne, maar eintlik nie demonstreer nie. Ten spyte van die spreker se verklarings word die dinge net genoem, sonder veel detail: "ek ken die hoeke en dakke/ van die geboue en huise/ om my ek weet waar smiddags laat/ en skemers vroeg die swart vlermuise/ uitborrel uit watter nokke". Die kennis word nie aan die leser oorgedra nie, en die verklarings is eerder 'n bevestiging van die spreker se grense en wat hy daarbinne ken. Sy klein huislike wêreldjie word selfs deur die oog van die voëls gesien - tot by die goggas as die kleinste vorm van lewe daarbinne. Presies waar dit in tyd en ruimte gesetel is, bly egter vaag.

In sterk kontras daarmee, word God buite dié grense geplaas. Hy stel meer belang in die sterre, gereduseer tot die geometriese bane - kegelsnitte - waarin hulle dinamies beweeg, as in die spreker se wêreldjie - ook gereduseer tot 'n geometriese patroon, 'n "klein kegel". Die paradoks word in die slot geformuleer: God sny as't ware deur die kegel, maar is as die Alomvattende ook bereid om Hom tot die spreker se wêreld te beperk. Hierdie paradoks is net formuleerbaar kragtens die skematisering tot grense en geometriese patrone. Nogtans, suggereer die metafoor van die kegel, is daar 'n analogie tussen die twee wêrelde: die verskillende figure kan herlei word tot snitte in die kegel; die kegel verteenwoordig die raakpunte tussen hulle. 
Hieruit is duidelik dat die skeppingsorde by Cloete vas lê binne sy duidelike grense: die mikrokosmos in verhouding tot die makrokosmos, met die mens as bevoorregte punt daarbinne (vgl. Foucault, 1973:32, 22). As hierdie grense nie deur die cogito, die reflekterende ek opgelê word nie, is die stelsel seker nie fenomenologies nie. Hoe belangrik refleksie egter wel in Cloete se poësie is, is myns insiens duidelik uit "Blydskap" ( $J: 108)$, een van sy bekendste gedigte.

\section{6. "Blydskap" en die fenomenologie van refleksie}

Ook "Blydskap" is 'n gedig wat sterk op die hier en die nou fokus. Dit word intern gefokaliseer deur 'n ek, maar die ek-figuur daarin sien baie meer konkrete en spesifieke detail raak wat tydruimtelik oënskynlik ook baie presieser geplaas word as in "alle dinghe bounding line" ( $I: 83)$ wat bykans geen konkrete detail van die omgewing verstrek nie.

\section{Blydskap}

Dit is Maandag

vandag die sewende van

die welige somermaand November

dit is in die jaar negentientagtig

van die Here. Oorkant my werk 'n man

met ' $n$ troffel en emmer

met water en steen. Skielik begin

in my die dinge een

na die ander

hulle liefderik bedrywig besin

op mekaar. Die steen

voel op hom die koggelmander

loop. Vir die son

blits die troffel. Die wind stuit

fladderend teen die blaar.

Groot droom iets ontasbaars in 'n kokon

klein 'n konkrete mot. Die ruit

laat die wolk in hom vaar.

Ek hoor die messelende man

wat werkende sing

bly gevoelig nadenkend nie vergeet

nie dat in die plan

van God, dat in sy skepping

die baie bewus en blydskap weet 
van die hardste steen en die dofste hout

op die presiese plek en die presiese uur

van elke vlerk en elke gewig

word behoudende sout

word suurdeeg wat deursuur

en verlig.

"Blydskap" handel ook oor eenheid en samehang. Daar is 'n sterk opposisie in die gedig tussen dit wat groot en omvattend is (en nie-telbaar) en die klein (telbare) dinge - dinge wat ook meestal nie-lewend en ongevoelig is (of ten minste dan, onbewus). Die steen (nie-lewend) voel die koggelmander; die wind stuit teen die blaar; die ruit laat die wolk in hom vaar. En veral natuurlik die verse: "Groot droom iets ontasbaars in 'n kokon/ klein 'n konkrete mot". Hier kry ons 'n paradoks op twee asse: nie net klein teenoor groot nie, maar ook abstrak teenoor konkreet.

Blydskap is die resultaat van hierdie paradoksale saambestaan van onversoenbaarhede, die bewussyn daarvan, die "liefderik bedrywig besin op mekaar" (v. 10-1). "Besin" is 'n sleutelwoord wat samehang en 'n wedersydse afhanklikheid suggereer, en dit is juis hierdie besinnende relasie wat blydskap produseer. Daarmee hang eintlik saam dat die verskillende elemente eienskappe aanneem van die ander elemente waarmee hulle in hierdie besinnende relasie tree. Hulle word dus metafore en daar vind 'n oordrag van eienskappe van die groot/ omvattende/ magtige (of bloot van die tweede element van die koppel - vgl. steen/koggelmander) af plaas na die ander. In hierdie hele proses word die abstrakte ook konkreet. Die omvattende word dus konkreet, maar ook bewiss. vol blydskap oor elke element in sy afsonderlike syn. Dit is veral ook 'n wete wat, veelseggend genoeg, op "vergeet" gerym word.

Op hierdie stadium kan die kem van die gedig voorlopig saamgevat word as die bewuste wedersydse ken van mekaar as deel van die omvattende. Natuurlik ken die dinge mekaar nie letterlik nie; dit is 'n metafoor vir hoe die waarnemer die toneel voor hom begryp.

\section{1 'n Beskrywingsisteem: die landskap van blydskap}

Die verskillende elemente wat genoem word, is egter nie lukraak saamgegooi nie. Hulle is elemente van die kode vir die beskrywing van dorpslandskappe mense wat werk, ruite, stene, wolke, blare - gewone, bekende dinge wat mens in 'n dorp kan waarneem. Die "die's" dui hulle bekendheid binne die raam van die dorpslandskap aan, maar hulle is natuurlik ook fyn geselekteerde, eksemplariese dinge van die dorpslandskap waarby ons self meer kan byvoeg. 
Die enigste een wat nie in 'n dorpslandskap hoort (bly, 'n tuiste het) nie, is die koggelmander. 'n Mens sou dalk eerder 'n akkedis of 'n geitjie verwag het maar "koggelmander" word deur 'n ander reël as die (vae) reëls vir dorpslandskappe gegenereer: die reël dat elke vierde vers rym. "Koggelmander" moet dus beskou word as 'n kodering van "(dorps)reptiel wat op stene/klippe loop", gekodeer binne die (verdere) rymkode van die gedig. "Blydskap" is dus ook die landskap gekenmerk deur blyheid - 'n blyd-skap.

In hierdie dorpslandskap is die mikro-makro-skema van die korresponderende kosmos nog sterk aan die werk in die opposisies tussen die omvattende en die kleine - veral die opposisie tussen groot, ontasbaar en klein, konkreet. 'n Mens kan maklik die weggelate rymwoord daar inlees: "God". "Groot droom iets ontasbaars" is kodewoorde vir God. Maar die skema word effens verskuil, en dit lyk of daar in die twee laaste strofes daaruit gebreek word, nes die sin daar neig om te ontspoor.

\subsection{Reduksies}

'n Bietjie moedswillig kan 'n mens sê dat die gedig sy effek bereik deur die normale verhoudinge tussen dinge/ elentente van die dorpslandskap om te keer en een stap te modifiseer. Die normale uitdrukking "singend werk" word hier "werkende sing". "Die wind stuit teen die fladderende blaar" word hier "die wind stuit fladderend teen die blaar". Dit lyk asof woorde bloot verskuif is; asof normale sintaktiese verhoudings verskuif raak. Kortom, die rigting van die kompeterende gelykenisse word omgedraai: dit is die klein, lokale dinge wat oorheers. Die blydskap is die gevolg van hierdie verskuiwings, en hulle word baie eksplisiet aangebied as subjektief, "in my", as effekte wat in die waarnemer plaasvind. Dit is sy bewussynstoestand, sy subjektiewe fokalisasie wat uitgedruk word.

In die laaste strofe maak hierdie verskuiwing plek vir verskeie reduksies waardeur ' $n$ verheerliking van elke ding in sy uniekheid en veral op sy unieke plek in sy eie unieke tyd ("die presiese plek en die presiese uur") tot stand kom. Hierdie reduksies berus op 'n weet wat nie rasioneel is nie, maar blydskaplik. Dit is 'n wete van God, van die omvattende, wat dáárom eintlik die rasionele te bowe gaan en allerlei Bybelse effekte moontlik maak, soos in die slotstrofe uitgedruk word: dit behou, dit preserveer, dit bewaar, dit suiwer ("deursuur"), dit verlig, dit vreet, pynig dalk selfs. Die gedig is dus 'n verheerliking van die unieke kennis van die plek en tyd, 'n blye wete wat soortgelyke effekte as die evangelie het.

Dit verklaar natuurlik, teruggeprojekteer, die baie presiese tydsaanduidings in strofe 1, Maandag, 7 November 1980: dit is 'n bewussyn van hierdie presiese 
tyd, 'n heilige tyd - die sewende dag (dag van die volmaakte) van die Here se jaar 1980. Daar begin die blydskap al.

Maar lees 'n mens die slotstrofe noukeurig, ontstaan daar 'n paar vrae:

van die hardste steen en die dofste hout

... weet

op die presiese plek en die presiese uur

Hout? Waar kom dit dan nou vandaan? Die steen was daar al in strofe 2. Hout is seker maar daar om 'n mooi, sterk kontras te vorm met steen. Dit is weliswaar deel van die huis wat die man vermoedelik aan 't bou is. Die blydskaplike weet werk hier egter met 'n geweldige reduksie, want die volheid van water, steen, wolk, blaar, koggelmander, wolk en mot word gereduseer tot twee opposisies: hard teenoor sag; helder teenoor dof.

En dan besef jy ook: die dinge wat genoem word, is nie die bonte veelheid van die natuur of die landskap self nie, maar enkele bekende en eksemplariese elemente daarvan - onmiskenbaar aangedui deur die die: die steen, die koggelmander, die son, die troffel, die ruit, die wolk, die messelende man, die presiese plek en die presiese uur. Dit was dus klaar 'n seleksie, 'n reduksie uit alle moontlike elemente: hoekom nie die buurman se foksterriër of die duiwemis op die stoep of die privetheining of die lamppaal of die stopteken ook in die gedig noem nie? En hoekom word so min individualiserende detail van die steen, die blaar of die man gegee? Ons weet nie of die steen rooi of grys is nie en of die man wit of swart is nie. Ons weet trouens nie eers wat "die presiese uur" is nie, al weet ons dis iewers op Maandag, 7 November 1980. Nog minder weet ons wat die presiese plek is - dit kan op enige plek in SuidAfrika geplaas word. Steen, troffel, man, mot, ruit verskyn hier dus in universele gedaantes, in hulle essensies, los van tyd en plek.

Daar is nog ' $n$ verdere opvallende reduksie in:

die presiese plek en die presiese uur

van elke vlerk en elke gewig

Hier verdwyn die dinge en bly net hulle dele of kwaliteite oor: hulle ligtheid of vlugtigheid en hulle gewig, en dit is hierdie kwaliteite wat bewaar, preserveer, suiwer en verlig. Let daarop dat "gewig" rym op "verlig". Die vervlugtiging van die substansie maak die verligting moontlik.

\subsection{Kritiek op refleksie}

'n Belangrike beginsel van hierdie gedig se konstruksie word myns insiens verberg in die metafoor "die ruit / laat die wolk in hom vaar". Letterlik: die 
ruit weerkaats die wolk. En die omgekeerde natuurlik ook: die ruit erken iets van homself in die wolk. Juis dit is 'n beginsel wat in al die koppels geld wat genoem word: die een vind iets van homself in die ander gereflekteer. Hierdie "blydskaplike wete" is ook 'n weerkaatsing van die een ding in die ander. "Vir die son blits die troffel" - hy gee vir die son sy eie refleksie terug. Die "liefderik bedrywig besin op mekaar", die "baie bewus en blydskaplik weet" is 'n selfbewussyn, maar veral ook 'n selfrefleksie, 'n selfweerkaatsing van die dinge. Dit spruit uit die paradoksale wyse waarop die een ding homself in die ander herken. En globaal genome, spruit dit uit die selfrefleksie van die spreker: hy herken homself in die ander dinge, projekteer sy bewussyn in hulle, word daardeur verlig. Hierdie blydskaplike wete is 'n selfkennis, op die ou end 'n weerkaatsing van die self - selfbeeld, blote herkenning en glad nie kennis nie. Die be-spiegelende bewussyn kry sy eie kategorieë tenuggekaats: "behoudende sout, suurdeeg wat deursuur / en verlig".

\section{Slot}

"Blydskap" is kortom 'n beskrywing van die werking van die cogito, die bespiegelende ek, in Cloete se poësie. Dit is teen hierdie agtergrond dat 'n woord soos "transendentaal" $(J: 57 ; \mathrm{I}: 39)$ by Cloete 'n wyer resonansie kry: die verskynsels kry hulle betekenis eers in die transendentale ruimte wanneer hulle presiese plek en tyd nie in die gewone tyd en ruimte nie maar in God se orde bepaal is. Cloete se poësie lyk of dit 'n digterlike fenomenologie van hierdie orde, van die heilige wete of ervaring van die dinge van God kan wees. Konkrete detail word uitgeëssensialiseer, dinge verskyn as transendentale "fenomene" (I: 52), "eideties" ( $D: 42)$. Hierdie woorde suggereer 'n verband met Husserl (1950/1964) se fenomenologie.

My gevolgtrekking is dus kortliks dat die Cloete-kyk fenomenologies is: die dinge self word beskou, nie in hulle uniekheid nie, maar soos hulle verskyn, gestroop van die 'transendente', van 'toevallighede' van tyd en plek (fenomenologiese reduksie) in die suiwer temporele stroom van die bewussyn. In hierdie ideaal-logiese dimensie van fenomene 'sien' 'n transendentale ego 'n ek wat eweneens fenomenologies gereduseer is - die universele logiese wese van die dinge raak (eidetiese reduksie), en hierdie logiese wese is 'n kennis van God. Die hele stelsel vorm 'n egologie: die kennis van die wese van die dinge kommunikeer die ego aan ditself in 'n soort alleenspraak waarvoor taal nie eintlik nodig is nie - 'n stelling wat al dadelik roep om heftige ontkenning; ons praat immers hier van 'n digter, 'n taalkunstenaar! Maar dit is myns insiens juis die wesenliker sin wat die cogito, die waarneming deur die transendentale ego, in Cloete se poësie lıtt. Dit tas die insinjes af op soek na God wat Hom bly verberg. 


\section{Bibliografie}

Bal, M. 1980. De theorie van vertellen en verhalen. Muiderberg : Coutinho. 2de druk.

Brink, A.P. 1985. Cloete se nuwe bundel sy kragtigste. Rapport, 15(27):17, Jul. 7.

Cloete, T.T. 1975. Die wêreld is ons woning nie. Kaapstad : Tafelberg. Vierde druk.

Cloete, T.T. 1980. Angelliera. Kaapstad : Tafelberg.

Cloete, T.T. 1982. Jukstaposisie. Kaapstad : Tafelberg.

Cloete, T.T. 1985. Allotroop. Kaapstad : Tafelberg.

Cloete, T.T. 1986. Idiolek. Kaapstad : Tafelberg.

Cloete, T.T. 1989. Driepas. Kaapstad : Tafelberg.

Cloete, T.T. 1992. Met die aarde praat. Kaapstad : Tafelberg.

Cloete, T.T. 1994. Die digter se omgaan met die werklikheid. Ensovoort, 6(1):6-7.

Foucault, M. 1973. The Order of Things. New York: Vintage.

Genette, G. 1980. Narrative Discourse. Trans. by Jane E. Lewin. Ithaca, New York : Cornell University Press.

Gräbe, I. 1985. Belangrike variasies op vorige temas. Die Transvaler: 6, Jul. 4.

Grové, A.P. 1987. Poësiekroniek: Leef uit 'n tradisie. Tydskrif vir Geesteswetenskappe, 27(2):148-156, Junie.

Husserl, E. 1950. Die Idee der Phänomenologie. Herausgegeben und eingeleitet von W. Biemel. Den Haag : Nijhoff. Edmund Husserl. Gesammelte Werke Bd. II.

Husserl, E. 1964. The Idea of Phenomenology. Trans. by W.P. Alston and G. Nakhnikian. Intro. by G. Nakhnikian. The Hague : Nijhoff. 2nd impression 1967.

Pretorius, R. 1981. Angelliera: van twee kante bekyk. Tydskrif vir Letterkunde, 19(2):77-83, Mei.

Rimon-Kenan, S. 1983. Narrative Fiction; Contemporary Poetics. London and New York: Methuen.

Schutte, H.J. 1984. 'n Poëtika van korrespondensies: Angelliera en Jukstaposisie. In: Viljoen, $\mathrm{H}$. et al. (reds.). In teen die groot vergeet. Potchefstroom : PU vir CHO. pp. 93-107.

Venter, L. 1988. "Philosophers are hard to kill". Tydskrif vir Geesteswetenskappe, 28(4):357-367, Desember.

Venter, L. 1991. Die praktyk van die kyk. Tydskrif vir Letterkunde, 29(3):6975, Augustus. 
